\title{
NORTHERN POCKET GOPHERS OCCUPY NEW TERRITORY
}

\author{
VICTOR C. FRIESEN, Box 65, Rosthern, Saskatchewan. SOK 3R0
}

A mammal which has benefited from prairie settlement, insofar as having more habitat accessible to it, is the Northern Pocket Gopher (Thomomys talpoides). In Saskatchewan it is "fairly common in certain areas of the province," with a range extending "to Prince Albert National Park." Yet this gopher - sometimes incorrectly called "mole" - is totally absent from other areas of seemingly suitable environment. Often a water course prohibits migration into an area until man facilitates it through bridge construction.

Such was the situation in the parkland region west of the South Saskatchewan River near the town of Rosthern. I had grown up on a farm between the two locations and, in going to either destination, had never seen evidence of pocket gophers. However, I was familiar with them. As a small boy, I had seen their diggings, with an active animal underneath, at the Saskatoon Exhibition Grounds in the early 1940s - and had examined a dead one, killed by a dog, at Wakaw Lake in the last years of that decade.

Banfield and Wrigley tell us that pocket gophers are highly sedentary. ${ }^{3,5}$ Their home range is about $125-175 \mathrm{~m}^{2}$, with animals often occupying the same region for the whole of their average three-year lifespan. Any advance into new territory, therefore, would tend to be slow.

The authors also point out that some individuals have been known to wander $1 \mathrm{~km}$ in search of better area, and one was once seen swimming across a river $300 \mathrm{~m}$ wide. The swift-flowing South Saskatchewan River near Rosthern, although of similar width, proved over the years to be a sufficient barrier to the gophers. (Pocket Gophers do not hibernate, but their forays in winter would not likely take them across any river ice. Their movements then are limited almost exclusively to subterranean wanderings in their tunnels below the frost line where they have caches of food, transported there in their cheek "pockets" during the previous fall.)

Then came 1968 and the construction of the $0.3 \mathrm{~km}$ Gabriel Bridge at the former ferry-crossing site. The succeeding years were marked by the presence of characteristic pocket-gopher diggings, now on land west of the river. In spring, with the melting of snow, the ditches of Highway 312 leading westward from the bridge were laced with earthen cores. These were $70-110 \mathrm{~mm}$ in diameter, some networks of them totalling $30 \mathrm{~m}$ in length (see photograph). These were the earthfilled casts of tunnels which were made through the snow in late winter and early spring when the animals bulldozed excess earth from below 


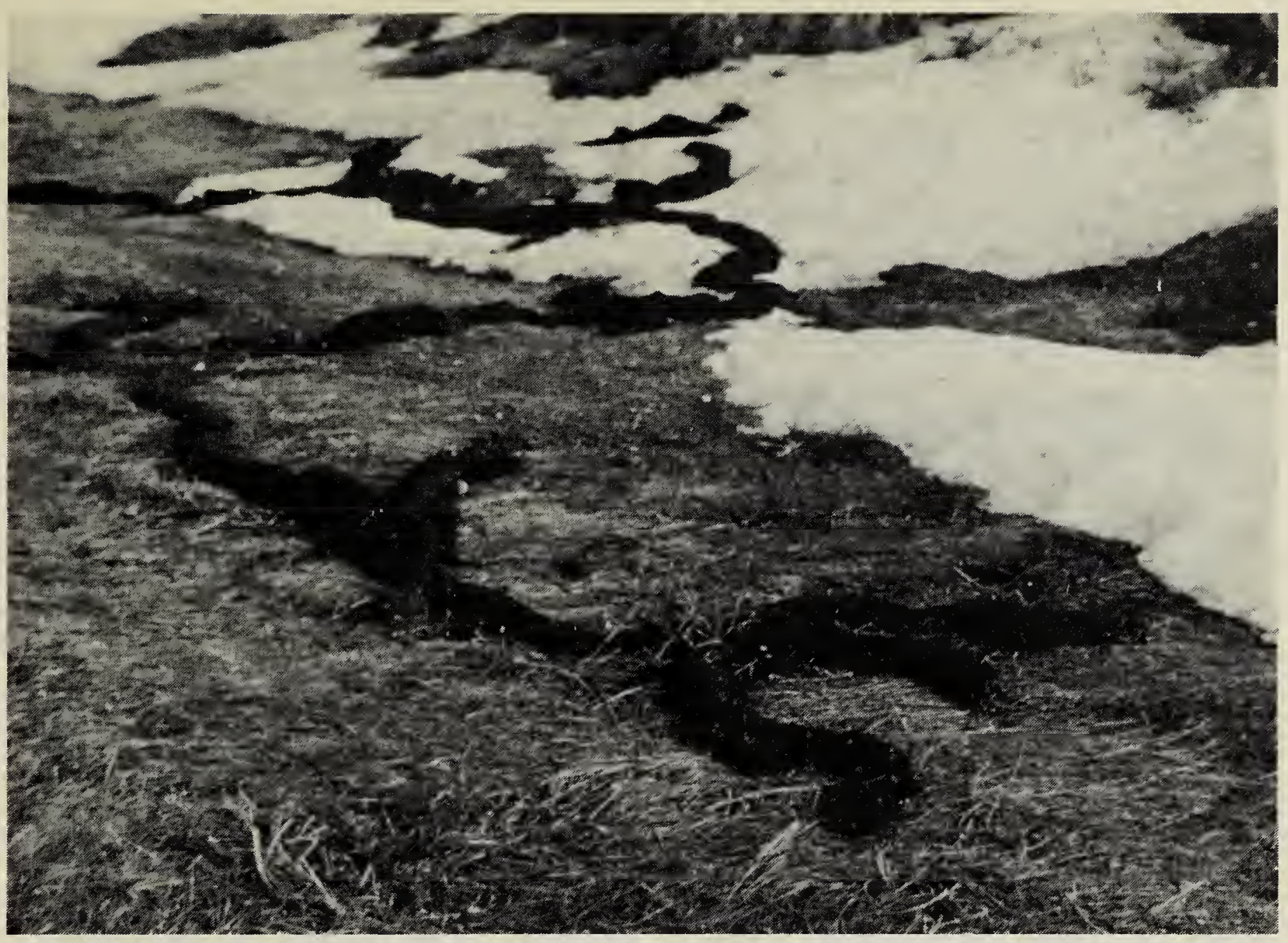

Network of diggings in roadside ditch near Rosthern, Saskatchewan evidence of Northern Pocket Gopher.

V.C. Friesen

into the snow tunnels of their foraging above surface.

By 1991 the area of telltale diggings and cores extended $4.5 \mathrm{~km}$ west of the river, and the district agrologist, writing in the local Rosthern newspaper, devoted an article to "Pocket Gophers - a Growing Problem." Gophers are partial to such crops as alfalfa and field peas, feeding on the green leaves and stems during nocturnal surface forays or else chewing roots from underground and pulling the plant down below. The concern among farmers, however, was not so much over crop loss, which is insignificant, compared to the damage done to haying and harvesting equipment from cutting into the protruding mounds of earth.

By the fall of 1991, the same newspaper reported that the Rural Municipality of Rosthern No. 403 had spent $\$ 2000$ in purchasing a special underground bait-setting plow which will be rented to farmers to control the spread of the pocket gophers. ${ }^{1}$ Since it is not practical to eliminate the animals completely, the Northern Pocket Gopher may now be considered as occupying new territory because of man's direct and specific alteration of the environment.

1. ANDREWS, R. 1991. R.M. going after moles. Saskatchewan Valley News, Sept. 18.

2. BADER, L. 1991. Pocket gophers - a growing problem. Saskatchewan Valley News, May 15.

3. BANFIELD, A.W.F. 1974. The mammals of Canada. Univ. of Toronto Press, Toronto. $438 \mathrm{pp}$.

4. BECK, W.H. 1958. A guide to Saskatchewan mammals. Sask. Nat. Hist. Soc., Spec. Publ. No. 1, Regina. 52 pp.

5. WRIGLEY, R.E. 1986. Mammals in North America. Hyperion Press, Winnipeg. $357 \mathrm{pp}$. 